\title{
INTERNATIONAL ORGANIZATION
}

\author{
Volume III
}

1949

\author{
BOARD OF EDITORS \\ Leland M. Goodrich, Chairman \\ M. Margaret BaLl \\ Grayson Kirk \\ William T. R. Fox \\ Dwight E. Lee \\ Harry C. Hawkins \\ Norman J. Padelford \\ JoSEPH E. JOHNSON \\ Walter R. Sharp \\ ROBERT B. STEWART \\ Raymond Dennett, Managing Editor \\ Margaret Bates, Associate Editor \\ Volume III, Copyright 1949, World Peace Foundation
}




\section{INTERNATIONAL ORGANIZATION}

Volume III - Number 1

FEBRUARY 1949

\section{BOARD OF EDITORS}

Leland M. Goodrich, Chairman

M. Margaret Ball

WILLIAM T. R. Fox

Harry C. Hawkins

JoSEPH E. JoHNSON

Grayson KIRK
Dwight E. LeE

Norman J. Padelford

W ALTER R. ShaRP

RoBERT B. StewarT

PAYson S. WILD

Raymond Dennett, Managing Editor Margaret Bates, Associate Editor 
International Organization is supported solely by the World Peace Foundation, a non-profit educational organization, and income from subscribers and advertisers. Statements of fact and opinion are made on the responsibility of the authors alone, and do not imply the endorsement of the Board of Editors or the Board of Trustees of the World Peace Foundation.

\footnotetext{
International Organization. Published quarterly by the World Peace Foundation. February 1949. Vol. III, No. 1. Editorial and Executive Offices, 40 Mt. Vernon Street, Boston 8, Mass. Entered as second-class matter Febru. ary 18, 1947, at the postoffice at Boston, Mass., under the act of March 3, 1879. Subscriptions $\$ 3.50$ a year. Individual copies $\$ 1.25$. Postage prepaid to any address.
}

\author{
VOLUME III, Number 1 \\ Copyright, 1949, World Peace Foundation \\ PRINTED IN U.S.A.
}




\section{TABLE OF CONTENTS}

\section{ARTICLES}

The Soviet Union, the United States and International SECURITY. Joseph E. Johnson . . . . . . . . . .

The Unted Nations and Domestic Jurisdiction. Leland $M$. Goodrich . . . . . . . . . . . . . . . 14

Control of International Am Transport. Virginia Little . . 29

INTERNATIONAL ORGANIZATIONS: SUMMARY OF ACTIVITIES

I. UNITED NATIONS

General Assembly . . . . . . . . . . . . . . . 46

Security Council . . . . . . . . . . . . . . . . . . 86

Economic and Social Council . . . . . . . . . . . 114

Trusteeship Council . . . . . . . . . . . . . . . . 130

Secretariat . . . . . . . . . . . . . . . 136

International Court of Justice $\quad . \quad$. . . . . . . . . . 139

II. SPECIALIZED AGENCIES

Food and Agriculture Organization . . . . . . . . . 142

Intergovernmental Maritime Consultative Organization . . 146

International Bank for Reconstruction and Development . . 147

International Civil Aviation Organization . . . . . . 150

International Labor Organization . . . . . . . . 152

International Monetary Fund . . . . . . . . . 154

International Refugee Organization . . . . . . . . . . . 156

International Telecommunication Union . . . . . . . 159

International Trade Organization . . . . . . . . . . . . 159

United Nations Educational, Scientific and Cultural Organization . . . . . . . . . . . . . . . 161

World Health Organization . . . . . . . . . . 163

III. REGIONAL ORGANIZATIONS

Arab League . . . . . . . . . . . . . . 165

Caribbean Commission

Consultative Council of Western Powers . . . . . . 166

Organization of American States . . . . . . . . . . . . . 169

IV. WAR AND TRANSITIONAL ORGANIZATIONS

Allied Commission for Austria . . . . . . . . . . . 174

Allied Control Council for Germany . . . . . . . . . . 175

Council of Foreign Ministers . . . . . . . . . . . . . . . . $\quad .178$

Far Eastern Commission . . . . . . . . . . . 180 
Inter-Allied Reparation Agency . . . . . . . . . 183 International Military Tribunal for the Far East . . . . 184 Organization for European Economic Cooperation . . . 186

DOCUMENTS ON INTERNATIONAL ORGANIZATIONS

I. DOCUMENTS ON THE UNITED NATIONS

1. Report of the Interim Committee of the General Assembly on the Problem of Voting in the Security Council, July 15, 1948 (excerpts) .

2. Universal Declaration of Human Rights, Approved by the General Assembly on December 10, 1948 . . . . 202

3. United Nations Convention on Genocide, Approved by the General Assembly on December 9, 1948 . . . . 206

4. Letter from the French Representative (Parodi) to the Security Council, September 29, 1948 . . . . . . 210

5. Resolution of the General Assembly on the Atomic Energy Commission, November 4, 1948 . . . . . 211

6. Resolution of the General Assembly on Permanent Missions to the United Nations, December 3, 1948 . . . 211

II. DOCUMENTS ON REGIONAL ORGANIZATIONS

American Treaty of Pacific Settlement, Signed at Bogotá,

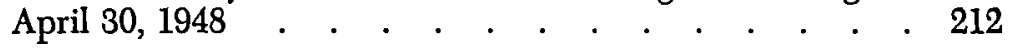

SELECTED BIBLIOGRAPHY. Robert K. Turner . . . . . . 226 